\title{
Stabilization of Returned Dairy Products by Ensiling with Straw and Molasses for Animal Feeding
}

\author{
Z. G. Weinberg, ${ }^{1}$ G. Ashbell, ${ }^{2}$ and Y. Chen ${ }^{3}$ \\ Forage Preservation and By-Products Research Unit, \\ The Volcani Center, \\ Bet Dagan \\ 50250, Israel
}

\begin{abstract}
Returned dairy products which are transferred to landfills might add to the environmental pollution. Such products have a high nutritional value for ruminants, but they should be stabilized to enable their use as cattle feed. The purpose of the current study was to examine stabilization of returned dairy products by ensiling in combinations with straw and molasses for animal feeding. Treatments included combinations of milk and cottage cheese with straw and molasses. Results indicate that such products ensile well with straw, and after $3 \mathrm{~d}$ of ensiling the $\mathrm{pH}$ decreased to around 4.0. It was necessary to supplement cottage cheese with molasses, to supply a carbohydrate source for the lactic acid fermentation. The major fermentation product was lactic acid. Percentage of ammonia N (of total N) was generally higher in the silages made with cottage cheese than in those made with milk; the highest percentage (16\%) was measured in the second experiment in the silages prepared with cottage cheese and straw. The study indicates the potential of stabilizing returned dairy products for animal feeding along with straw and molasses. There may also be potential for large dairy farms, or groups of smaller farms, to ensile waste milk with straw for later use as feed.
\end{abstract}

(Key words: dairy products, ensiling, cattle feeding)

Abbreviation key: WSC = water soluble carbohydrates.

\section{INTRODUCTION}

Many dairy products are returned from the grocery stores because the sale-by date has been reached or because of spoilage, which is enhanced in warm climate, in spite of cooling systems. In Israel out of the billionliter market of dairy products about $2 \%$ are returned.

Received May 1, 2002.

Accepted August 15, 2002.

Corresponding author: Z. G. Weinberg; e-mail: zgw@volcani.agri. gov.il.
These include milk, soft cheeses, and cream. The returned dairy products are transferred along with municipal trash to landfills and contribute to the environmental load. Effluent from spoiling dairy products might leak into underground water sources and result in pollution. The biological oxygen demand values for wastewater generated in the dairy industry are 500 to 700 and 1500 to $2000 \mathrm{ppm} \mathrm{O}_{2}$, for milk and cheese, respectively (Wheatley, 1994). The values for the actual dairy products might be much higher.

Milk and dairy products have a high nutritional value for animals due to their protein, fat, sugar, and mineral content. Therefore, it would be beneficial to utilize returns of such products for animal feeding. All products are originally prepared from pasteurized milk and therefore, the potential health hazards to animals consuming such products are minimal. However, for efficient utilization the returned dairy products should be stabilized to enable short-term storage and handling. Stabilization of returned products should be cost efficient. One possibility for preservation is ensiling which is a preservation method for moist crops. Ensiling is based on spontaneous solid-state fermentation whereby lactic acid bacteria convert water-soluble carbohydrates into organic acids, mainly lactic acid. As a result the $\mathrm{pH}$ decreases, and the forage is preserved. Returned dairy products are too moist for ensiling because of potential fermentation and effluent problems. Therefore, it would be desirable to mix them with a dry material to absorb excess moisture. Sugar addition may be necessary to adequate fermentation.

The purpose of the current work was to study the ensiling properties of dairy products in combination with straw and molasses.

\section{MATERIALS AND METHODS}

Fresh homogenized milk (3\% fat) and cottage cheese ( $5 \%$ fat) packed in $2 \mathrm{~kg}$ plastic bags were donated by a local dairy plant. Two ensiling experiments were performed: immediately upon receipt and 1 wk later on the sale-by date. The products were stored at $4^{\circ} \mathrm{C}$ until used. 
Table 1. Analysis of the fresh materials. Lactobacilli are given as $\log _{10}$ number of colony forming units $\mathrm{g}^{-1}$.

\begin{tabular}{|c|c|c|c|c|c|c|c|}
\hline & \multirow[b]{2}{*}{ DM, g/kg } & \multicolumn{2}{|c|}{$\mathrm{pH}$} & \multicolumn{2}{|c|}{$\mathrm{WSC}^{2}, \mathrm{~g} / \mathrm{kg}$} & \multicolumn{2}{|c|}{ Lactobacilli } \\
\hline & & Exp. 1 & Exp. 2 & Exp. 1 & Exp. 2 & Exp. 1 & Exp. 2 \\
\hline Straw $^{1}$ & 862 & 3 & 6.7 &..$^{3}$ & 24 & 3 & 4.6 \\
\hline Cottage cheese & 198 & 5.2 & 5.5 & 9 & 0 & 6.4 & 6.8 \\
\hline Milk & 115 & 7.0 & 6.8 & 33 & 38 & $<2.0$ & 5.8 \\
\hline
\end{tabular}

\footnotetext{
${ }^{1}$ Rumen degradability of the straw $605 \pm 21 \mathrm{~g} / \mathrm{kg}$; no yeasts or molds were detected in the milk or in the cottage cheese.

${ }^{2} \mathrm{WSC}=$ water-soluble carbohydrates.

${ }^{3}$ Not measured.
}

Treatments were comprised of mixtures of dairy products and wheat straw to obtain adequate DM composition for ensiling (approximately $350 \mathrm{~g} / \mathrm{kg}$ ), with or without molasses as a carbohydrate source. The same wheat straw and molasses were used in both experiments.

\section{Experiment 1}

The following treatments were prepared in triplicates: 1) $830 \mathrm{~g}$ cottage cheese mixed with $75 \mathrm{~g}$ chopped wheat straw, 2) treatment 1 plus 26 g molasses, 3) 700 g milk mixed with $265 \mathrm{~g}$ chopped straw, and 4) $465 \mathrm{~g}$ of treatment 3 mixture plus $15 \mathrm{~g}$ molasses. The various mixtures were ensiled in 0.25 -L sealed jars and stored for $30 \mathrm{~d}$ at $30^{\circ} \mathrm{C}$. The wet weights were $185 \pm 7$ and 118 \pm 2 g per jar, respectively, for the cottage cheese and straw and for the milk and straw mixtures, respectively.

\section{Experiment 2}

The treatments were prepared as follows: 1) $3 \mathrm{~kg}$ of cottage cheese were mixed with $0.75 \mathrm{~kg}$ of chopped straw, 2) one-half of treatment 1 plus $50 \mathrm{~g}$ molasses, 3) $2.85 \mathrm{~kg}$ milk were mixed with $1.15 \mathrm{~kg}$ of chopped straw, and 4) one-half of treatment 3 plus $50 \mathrm{~g}$ molasses. The various mixtures were ensiled in 0.25 -L sealed jars and stored at $30^{\circ} \mathrm{C}$. There were nine jars per treatment, and three were opened on $\mathrm{d} 3,7$, and 36 to follow fermentation dynamics. The wet weights were $110 \pm 8$ and 134 $\pm 7 \mathrm{~g}$ per jar for the cottage cheese and straw and for the milk and straw mixtures, respectively.

\section{Analyses}

Chemical analyses of the raw materials and fresh mixtures were conducted on pooled single samples, and analyses of the silages were performed on individual jars (triplicates). Dry matter was determined by oven drying for $48 \mathrm{~h}$ at $60^{\circ} \mathrm{C}$. Crude protein was determined by the Kjeldahl method (AOAC, 1980). Ammonia N was determined by the Kjeldahl method without the digestion step as follows: a $40 \mathrm{~g}$ sample was extracted in 360 $\mathrm{ml}$ distilled water in a Stomacher blender for $3 \mathrm{~min}$. The extract was filtered through Whatman No 1 paper, and $100 \mathrm{ml}$ was processed in a Kjeltech auto 1030 analyzer (Tecator, Sweden). Water-soluble carbohydrates (WSC) were determined by the phenol-sulfuric acid method according to Dubois et al. (1956). Lactic acid was determined by a spectrophotometric method according to Barker and Summerson (1941). Volatile fermentation products were determined in aqueous extracts by means of a GLC with a semi-capillary FFAP (nitroterephthalic acid-modified polyethylene glycol)

Table 2. Chemical analysis of the ensiled dairy products after $30 \mathrm{~d}$ of ensiling-Experiment 1 . Results are in $\mathrm{g} / \mathrm{kg}$ of DM, except as noted.

\begin{tabular}{llllllllll}
\hline & & & & Lactic & Acetic & Crude & & \\
Treatment $^{1}$ & DM g/kg & pH & WSC $^{4}$ & acid & acid & Ethanol & protein & $\mathrm{NH}_{3}-\mathrm{N} \% / \mathrm{TN}^{4}$ & $\mathrm{RD}^{4}$ \\
\hline $1^{2}$ & 303 & $5.7^{\mathrm{a} 3}$ & $10^{\mathrm{c} 3}$ & $6^{\mathrm{c} 3}$ & $18^{\mathrm{a} 3}$ & $5^{\mathrm{a} 3}$ & $394^{\mathrm{a} 3}$ & $13^{\mathrm{a} 3}$ & $710^{\mathrm{b} 3}$ \\
2 & 307 & $4.9^{\mathrm{b}}$ & $6^{\mathrm{c}}$ & $27^{\mathrm{b}}$ & $19^{\mathrm{a}}$ & $6^{\mathrm{a}}$ & $381^{\mathrm{b}}$ & $7^{\mathrm{b}}$ & $799^{\mathrm{a}}$ \\
3 & 327 & $3.9^{\mathrm{c}}$ & $26^{\mathrm{b}}$ & $49^{\mathrm{a}}$ & $10^{\mathrm{b}}$ & $0^{\mathrm{b}}$ & $130^{\mathrm{c}}$ & $2^{\mathrm{c}}$ & $617^{\mathrm{c}}$ \\
4 & 341 & $3.9^{\mathrm{c}}$ & $46^{\mathrm{a}}$ & $45^{\mathrm{a}}$ & $8^{\mathrm{b}}$ & $0^{\mathrm{b}}$ & $128^{\mathrm{c}}$ & $1^{\mathrm{c}}$ & $707^{\mathrm{b}}$ \\
\hline
\end{tabular}

${ }^{1}$ Treatments: 1) cottage cheese and straw; 2) cottage cheese, straw, and molasses; 3) milk and straw; 4) milk, straw, and molasses.

${ }^{2}$ Treatment 1 contained also $5 \mathrm{~g} \mathrm{~kg}^{-1} \mathrm{DM}$ butyric acid.

${ }^{3}$ Within a column, means followed by different superscripts are significanly different $(P<0.05)$.

${ }^{4} \mathrm{WSC}=$ water-soluble carbohydrates; $\mathrm{TN}=$ total nitrogen; $\mathrm{RD}=$ rumen degradability. 
Table 3. Microbiological analysis of the ensiled dairy products after $30 \mathrm{~d}$ of ensiling-Experiment 1. Results are given as $\log _{10}$ number of colony forming units $\mathrm{g}^{-1}$.

\begin{tabular}{llll}
\hline Treatment $^{1}$ & Lactobacilli & Yeasts & Molds \\
\hline 1 & 8.5 & $<2.0$ & $<2.0$ \\
2 & 8.5 & $<2.0$ & $<2.0$ \\
3 & 7.4 & $<2.0$ & $<2.0$ \\
4 & 7.0 & $<2.0$ & 2.9 \\
\hline
\end{tabular}

${ }^{1}$ Treatments: 1) cottage cheese and straw; 2) cottage cheese, straw, and molasses; 3) milk and straw; 4) milk, straw, and molasses.

column (Hewlett Packard, Waldbronn, Germany) over a temperature range of 40 to $230^{\circ} \mathrm{C}$. Rumen degradability was measured after $48 \mathrm{~h}$ by the in situ procedure of Meherez and Ørskov (1977). Lactobacilli were enumerated via pour-plate technique in Rogosa agar (Oxoid) and yeasts and molds by spread plate on malt extract agar (Oxoid) acidified to $\mathrm{pH} 4.0$ with $10 \%$ lactic acid. The plates were incubated at $30^{\circ} \mathrm{C}$ for $3 \mathrm{~d}$.

Statistical analysis included ANOVA and Duncan's multiple range test using the SAS general linear means procedure (SAS, 1982).

\section{RESULTS}

Table 1 gives the analyses of the raw materials for both ensiling experiments. After $1 \mathrm{wk}$ of storage at $4^{\circ} \mathrm{C}$, the number of lactobacilli in the milk increased considerably. However, increased lactobacilli numbers did not decrease the $\mathrm{pH}$ nor WSC content of the milk; $\mathrm{pH}$ even increased slightly, probably due to protein breakdown. Molasses was not analyzed and was assumed to contain $50 \%$ WSC (Ashbell et al., 1995).

Table 2 gives the analyses of the resulting dairy products and straw silages after $30 \mathrm{~d}$ of ensiling in experiment 1 . Mixing the dairy products with the straw was designed to obtain a DM content above $350 \mathrm{~g} \mathrm{~kg}^{-1}$ according to the DM content of the separate ingredients. The ratio at which cottage cheese and straw were combined in this experiment resulted in somewhat lower $\mathrm{DM}$ than expected. The $\mathrm{pH}$ of the cottage cheese and

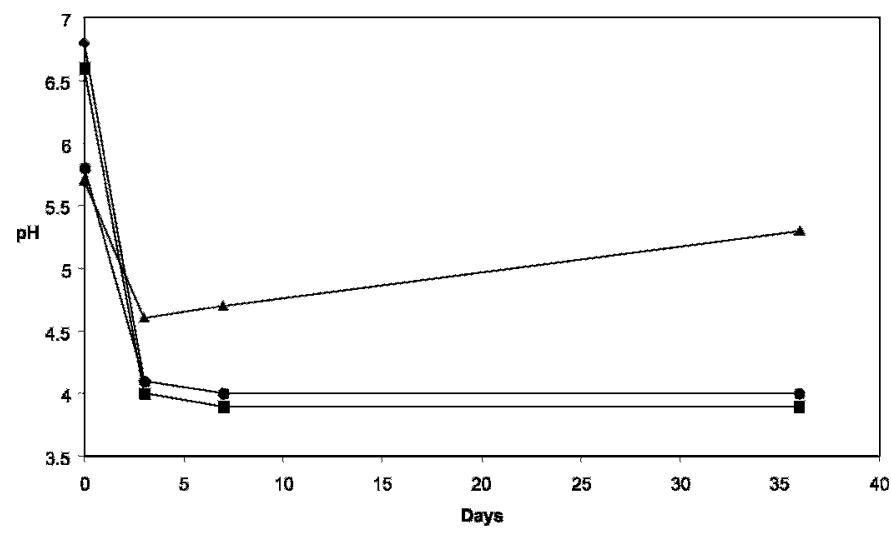

$-\bullet$ Milk-straw $\rightarrow-$ Milk-straw-molasses $\rightarrow-$ Cattage-straw $\rightarrow-$ Cottage-straw-molasses

Figure 1. $\mathrm{pH}$ change during ensiling of dairy products with straw and molasses.

straw mixture decreased only in the treatment that was augmented with molasses as a carbohydrate source for the fermentation. The butyric acid found in the cottage cheese and straw silages may suggest the beginning of clostridial fermentation in that treatment. The milk and straw mixture fermented readily even without molasses due to the relatively high lactose content of the milk, as seen from the decrease in $\mathrm{pH}$ and build-up of lactic acid, the major fermentation product. The RD of the cottage cheese and straw silages were higher than straw, but RD of the milk and straw silages were similar to straw. Lactobacilli were the major microbial population, of those measured, in all silages (Table 3). The number of lactobacilli in the cottage cheese mixtures (treatments 1 and 2) were a log cycle higher than in the milk combinations (treatments 3 and 4); yet the $\mathrm{pH}$ was higher and the lactic acid content lower in the treatments containing cottage cheese (Table 2). This result is attributed to the cottage cheese being a lactic acid fermentation product, so lactic acid bacteria numbers had increased and WSC had been depleted during its manufacturing. The milk had more WSC (lactose)

Table 4. Chemical analysis of the ensiled dairy products after $36 \mathrm{~d}$-Experiment 2 . Results are in $\mathrm{g} \mathrm{kg}^{-1}$ DM.

\begin{tabular}{llllllllll}
\hline & & & & Lactic & Acetic & Crude \\
Treatment & & DM & $\mathrm{pH}$ & $\mathrm{WSC}^{3}$ & acid & acid & Ethanol & $\begin{array}{l}\text { protein } \\
\mathrm{NH}_{3}-\mathrm{N} \% / \mathrm{TN}^{3}\end{array}$ & $\mathrm{RD}^{3}$ \\
\hline 1 & 362 & $5.3^{\mathrm{a} 2}$ & $0^{\mathrm{c} 2}$ & $25^{\mathrm{b} 2}$ & $10^{\mathrm{b} 2}$ & 4 & $225^{\mathrm{b} 2}$ & $16^{\mathrm{a} 2}$ & $601^{\mathrm{b} 2}$ \\
2 & 359 & $4.0^{\mathrm{b}}$ & $5^{\mathrm{c}}$ & $86^{\mathrm{a}}$ & $4^{\mathrm{b}}$ & 0 & $282^{\mathrm{a}}$ & $4^{\mathrm{d}}$ & $646^{\mathrm{a}}$ \\
3 & 339 & $4.0^{\mathrm{b}}$ & $14^{\mathrm{b}}$ & $92^{\mathrm{a}}$ & $17^{\mathrm{a}}$ & 4 & $113^{\mathrm{c}}$ & $10^{\mathrm{b}}$ & $480^{\mathrm{c}}$ \\
4 & 338 & $3.9^{\mathrm{b}}$ & $41^{\mathrm{a}}$ & $97^{\mathrm{a}}$ & $9^{\mathrm{b}}$ & 0 & $118^{\mathrm{d}}$ & $5^{\mathrm{c}}$ & $490^{\mathrm{c}}$ \\
\hline
\end{tabular}

${ }^{1}$ Treatments: 1) cottage cheese and straw; 2) cottage cheese, straw, and molasses; 3) milk and straw; 4) milk, straw, and molasses.

${ }^{2}$ Within a column, means followed by different superscripts are significantly different $(P<0.05)$.

${ }^{3} \mathrm{WSC}=$ water-soluble carbohydrates; $\mathrm{TN}=$ total nitrogen; $\mathrm{RD}=$ rumen degradability. 
Table 5. Numbers of lactobacilli in the ensiled dairy products in Experiment 2. Results are given as $\log _{10}$ number of colony forming units $\mathrm{g}^{-1}$.

\begin{tabular}{lllll}
\hline Treatment $^{1}$ & Day 0 & Day 3 & Day 7 & ${\text { Day } 36^{2}}^{2}$ \\
\hline 1 & 6.9 & 10.0 & 9.4 & 8.1 \\
2 & 9.6 & 10.0 & 9.1 & 5.5 \\
3 & 6.0 & 9.3 & 9.6 & 8.6 \\
4 & 8.7 & 9.7 & 8.7 & 8.9 \\
\hline
\end{tabular}

${ }^{1}$ Treatments: 1) cottage cheese and straw; 2) cottage cheese, straw, and molasses; 3) milk and straw; 4) milk, straw, and molasses.

${ }^{2}$ On d 36 Treatment 1 had also 3.2 and 5.7 yeasts and molds, respectively.

available for the ensiling fermentation that permitted accumulation of lactic acid and decreased $\mathrm{pH}$.

Figure 1 gives the change in $\mathrm{pH}$ during ensiling of the mixtures of dairy products and straw (experiment 2). Except for the cottage cheese and straw treatment, all treatments fermented well, and even by d 3 their $\mathrm{pH}$ values were approximately 4.0.

The higher proportion of straw in these mixtures resulted in a higher DM content in experiment 2 (Table 4). Overall, the results of experiment 2 were similar to experiment 1 , in that cottage cheese and straw mixtures needed molasses addition to ensile properly. The silages that comprised of cottage cheese mixtures in experiment 2 had a wider lactic acid to acetic acid ratio than in experiment 1 . The improved fermentation of these mixtures can be attributed to the higher DM content and to lower buffering capacity with extra straw. Crude protein content in the second experiment was lower than in experiment 1 , probably due to protein breakdown during the 1-wk storage, or due to the greater dilution of straw. The percentage of ammonia N (of total N) was generally higher in the silages containing cottage cheese than in silages that included milk; ammonia levels increased in the silages prepared with milk in the second experiment compared to experiment 1 . The highest percent of ammonia $\mathrm{N}$ of total $\mathrm{N}$ was $16 \%$, measured in the second experient in the silages prepared with cottage cheese and straw, indicating only moderate proteolysis.

Rumen degradability decreased in all treatments in experiment 2, as compared with experiment 1 , even below the value of straw, which we cannot explain. Table 5 gives the microbial counts during the ensiling period of experiment 2 . Results indicate that the numbers of lactobacilli were high in all treatments even by the $3 \mathrm{rd} \mathrm{d}$ of ensiling.

\section{DISCUSSION}

Utilization of returned dairy products for cattle feeding could benefit both the environment and the animal industry. The results of the current experiments indi- cate that it is possible to stabilize returned dairy products for animal feeding by ensiling. Ensiling moist dairy products along with straw seems a feasible technology for such commodities. A similar technology is being used in the preservation of citrus peels for animal feeding. Due to high yeast populations the moist peels without amendment undergo an ethanolic fermentation with substantial losses (Ashbell et al., 1987). Therefore, an economical way to stabilize the moist peels is to coensile them with dry broiler litter, a common practice on farms in Israel (Ashbell et al., 1995).

Some returned processed dairy products may not contain enough fermentable carbohydrates necessary for ensiling, as was the case with cottage cheese. They may require addition of an inexpensive source of sugars. However, in a commercial operation, various types of returned dairy products may possibly be combined to provide enough carbohydrates for the ensiling without further addition of other sugar sources.

The current study is only the first step towards realization of such technology. More studies are required to test this idea in larger scale. One problem associated with this technology might be the separation of the dairy products from the packaging materials. It could well be that a press that squeezes out the products from the package may be a solution. Utilization of waste milk from large dairy farms or from groups of farms by ensiling with straw for later use as feed seems more feasible at present, as it does not require the separation of products from small containers.

\section{ACKNOWLEDGMENTS}

Contribution from the Agricultural Research Organization, The Volcani Center, Bet Dagan, Israel No. 427/ 00, 2002 series.

\section{REFERENCES}

AOAC. 1980. Official Methods of the Association of Official Analytical Chemists. 12th ed. Washington, D.C.

Ashbell, G., G. Pahlow, B. Dinter, and Z. G. Weinberg. 1987. Dynamics of orange peel fermentation during ensilage. J. Appl. Bacteriol. 63:275-279. 
Ashbell, G., Z. G. Weinberg, and Y. Hen. 1995. Studies of quality parameters of variety ensiled broiler litter. Anim. Feed Sci. Technol. 52:271-278.

Barker, S. B., and W. H. Summerson. 1941. The colorimetric determination of lactic acid in biological material. J. Biol. Chem. 138: $535-554$

Dubois, M., K. A. Gilles, J. K. Hamilton, P. A. Rebes, and F. Smith. 1956. Colorimetric method for determination of sugars and related substances. Anal. Chem. 28:350-356.
Meherez, A. D., and E. R. Ørskov. 1977. A study of the artificial fiber bag technique for determining the digestibility of feed in rumen. J. Agric. Sci. 88:645-650.

SAS User's Guide: Statistics. 1982. SAS Inst., Inc., Cary, NC.

Wheatley, A. D. 1994. Water pollution in the food industry: Sources, control and cost implications. Pages 137-263 in Food Industry and the Environment, 1st ed. J. M. Dalzell, ed., Blackie Academic \& Professional, London. 